\title{
Flood defence alternatives for the lower Bío Bío River, Chile
}

\section{Alternativas de defensas contra inundaciones para la parte baja del río Bío Bío, Chile}

Fecha de entrega: 30 de septiembre 2013

Fecha de aceptación: 5 de diciembre 2013

\section{Constant van Heemst ${ }^{1}$, Joost Willems ${ }^{1}$, Anthonie Weller ${ }^{1}$, Huub van Verseveld $^{1}$, Diego Caamaño ${ }^{2}$ and Rafael Aránguiz ${ }^{2,3}$}

${ }^{1}$ Faculty of Civil Engineering and Geosciences, Delft University of Technology, Stevinweg 1, PO-box 5048, 2628 CN Delft, 2600 GA Delft, The Netherlands, C.vanHeemst@student.tudelft.nl, J.A.Willems@student.tudelft.nl, A.H.C.Weller@student.tudelft.nl, H.C.W.vanVerseveld@student.tudelft.nl

${ }^{2}$ Department of Civil Engineering, Universidad Católica de la Santísima Concepción, Alonso de Ribera 2850, Casilla 297, Concepción, Chile, dcaamano@ucsc.cl, raranguiz@ucsc.cl

${ }^{3}$ Centro Nacional de Investigación para la Gestión Integrada de Desastres Naturales (CIGIDEN)

The Bio Bio River is the second largest river in Chile considering both discharge and length. The Bio Bio River flows through the second most important economical centre in Chile and it has been recently classified as one of the world's largest river systems strongly affected by fragmentation and change in flow regime, mainly due to hydropower and irrigation. The cities of Hualqui, Chiguayante, Concepción, Hualpén, and San Pedro de la Paz are located along the last $25 \mathrm{~km}$ of its course, and are exposed to a high flood risk due to a combination of increasing rainfall storms and the dams operation located in the upper basin. This work assessed several structural and non-structural flood defence alternatives for the lower $25 \mathrm{~km}$ of the river. A one-dimensional (1D) hydraulic model was used under different discharge scenarios. The results showed that storage areas and diversion canals located along the lower part of the Bio Bio River did not prove to be a suitable solution. Nevertheless, it was found that the most effective alternative implies a reservoir operation focused on storing the extra water produced by the incoming flood. Conclusions support the materialization of reservoir emergency operation protocols, as indicated in the Reglamento de Ley $N^{\circ} 20.304$, approved by Decreto de Ley 138, Chile.

Keywords: Bio Bio River, flood risk, flood defence, hydraulic model, reservoir operation
El río Bío Bío es el segundo más grande de Chile en cuanto a caudal y largo; fluye a través de la segunda zona económica más importante de Chile y ha sido recientemente clasificado como uno de los sistemas fluviales más grandes del mundo afectado fuertemente por fragmentación $y$ cambio de régimen de flujo, debido principalmente a la producción hidroeléctrica y el riego. Las ciudades de Hualqui, Chiguayante, Concepción, Hualpén y San Pedro de la Paz se encuentran ubicadas a lo largo de los últimos $25 \mathrm{~km}$ de su curso y están expuestas a un alto riesgo de inundación debido a la combinación de intensos frentes de lluvia y la operación de represas ubicadas en la parte alta de la cuenca. En este trabajo se evalúan varias alternativas de defensas fluviales, estructurales y no estructurales, para los últimos $25 \mathrm{~km}$ del río. Se ha utilizado un modelo hidráulico unidimensional (1D) bajo diferentes escenarios de caudales. Los resultados muestran que no son soluciones adecuadas, a lo largo de la parte baja del río Bío Bío, las áreas de almacenamiento y los canales de desvio. No obstante, se encontró que la alternativa más efectiva implica una operación de embalse que apunte a almacenar el exceso de agua que producirian las inundaciones. Las conclusiones ratifican la materialización de los protocolos de operación de emergencia de embalses, como se indica en el Reglamento de Ley No20.304, aprobado por Decreto de Ley 138, Chile.

Palabras clave: río Bío Bío, riesgo de inundación, defensa fluvial, modelo hidráulico, operación de embalse 


\section{Introduction}

During the year of 2006 the lower Bío Bío River experimented a 100-year flood that left urban areas under water. Approximately $15700 \mathrm{~m}^{3} / \mathrm{s}$ were registered at the Dirección General de Aguas DGA gauging station located $11 \mathrm{~km}$ upstream the Bío Bío River mouth (Figure 1).

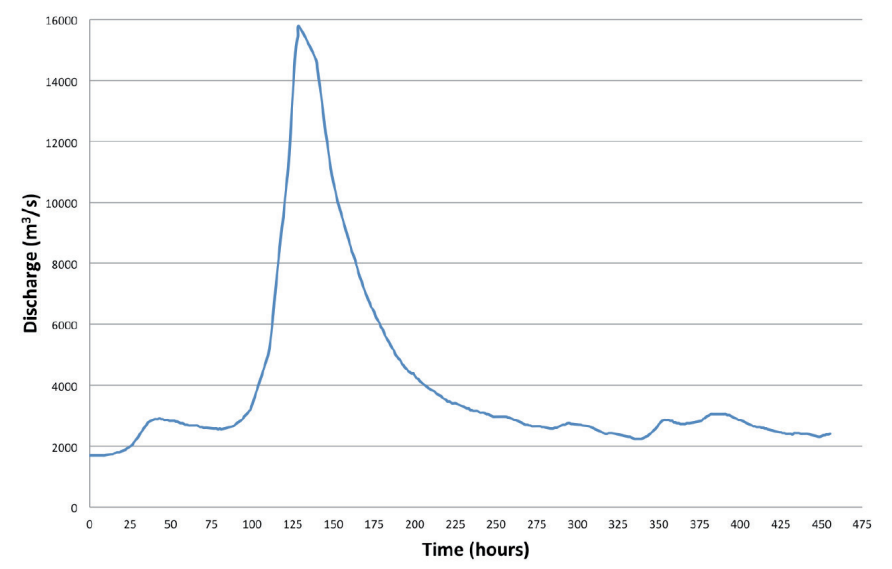

Figure 1: Hydrogram from 2006-flood event at the lower Bío Bío River. The flood started on July 10th approximately at 4 am

This large amount of water caused severe damage to the infrastructure, industry and urban areas. However, specific characteristics of the total damage are unknown, the National Emergency Office (ONEMI, 2012) states the following statistics: a) 95862 people were affected by the floods; 28177 of them were severely affected, b) 400 people were placed in shelters, c) 682 homes sustained major damage, d) 13267 homes experienced minor damage, e) 75 homes were destroyed, f) 19 people were killed, and g) 2 people are missing. Five cities located within the lower $25 \mathrm{~km}$ of the Bío Bío River were affected by the 2006 flood and they are still under high flood risk. Therefore, a strategy to protect these localities is needed.

A HEC-RAS model (U.S. Army Corps of Engineers, 2010) was built to cover a series of pre-design scenarios. Modelling efforts were focused on assessing a strategy to reduce risks and damage due to future floods. The project area was defined from the river mouth up to a length of $22 \mathrm{~km}$ upstream. The required modelling information was obtained from different sources. Bathymetry was available through the Ministry of Public Works (MOP for its name in Spanish) and complemented by surveyed data collected by Caamaño (2010). Discharge information was provided by the local Water Agency (DGA for its name in Spanish) and tidal levels were obtained from the Hydrographic and Oceanographic Service of the Chilean Navy (SHOA for its name in Spanish). Roughness and velocities were also collected by Caamaño (2010) and used on this modelling study. Then, the morphology and the hydraulic properties were recognized, to further explore several flood mitigation alternatives in order to select the ones that are being assessed by means of the 1D hydraulic model.

\section{Study site description}

The watershed of the Bío Bío River corresponds to an area of $24264 \mathrm{~km}^{2}$ (MOP, 2004). The River has its origin in the Andes at the lakes Icalma and Galletué at an altitude of 1300 $\mathrm{m}$ above sea level. The main course travels more than 380 $\mathrm{km}$ down to the river mouth at the Pacific Ocean. Along the course through the Andes valley, the river receives melting water and runoff from the mountains (Parra, 2006). Figure 2 shows the location of the Bío Bío River, as well as the main course and tributaries. In the downstream direction the river increases its width and the discharge rises due to the tributaries incoming water.

The annual average discharge at the lower part of the Bío Bío River is estimated to be $1000 \mathrm{~m}^{3} / \mathrm{s}$. Two major dams are located along the main course of the Bío Bío River, Pangue and Ralco (Figure 2). The water that flows through the Pangue Dam, located $239 \mathrm{~km}$ upstream, contributes on average with $40 \%$ of the discharge that reaches the mouth. Two main tributaries contribute with $20 \%$, these are the Laja River with $15 \%$ and the Vergara River with $5 \%$. Smaller tributaries, along with distributed runoff, supply with the other $40 \%$ of the total discharge at Concepción.

\section{Hydraulic model for current Bío Bío conditions}

The modelling domain corresponds to the lower $22 \mathrm{~km}$ of the river, thus the efficiency of the different assessed strategies to protect the main populated areas and important industries can be assessed. From the local geographic configuration, eleven relevant areas can be identified and considered in the analysis. The areas are the following: 1) Bío Bío submarine canyon, 2) migrating sand bar, 3) wetlands on the northern bank, 4) refinery, 5) creek on 
the south bank (i.e. estero Los Batros), 6) floodplain at the southern bank, 7) Hualpén, 8) San Pedro de la Paz, 9) Concepción, 10) bridges, and 11) Chiguayante (Figure 3).

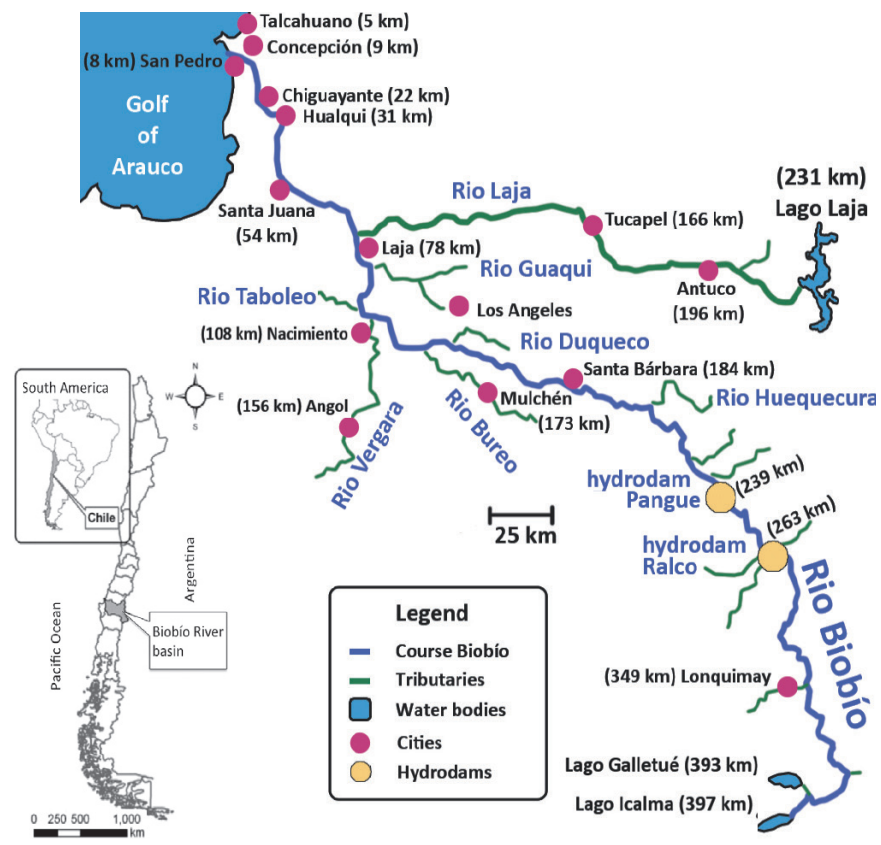

Figure 2: Location of the study site Bío Bío River basin location within South America and Bío Bío basin river network showing distances to the river outlet

Figure 4 shows aerial photographs, which were used to describe the flooded areas within the modelling domain during the 2006 flood event. The estimated flooded areas are shown in Figure 5. For example, it is possible to identify a large flooded area of about $12 \mathrm{~km}^{2}$ located west of Hualpén, which corresponds to an old river course, and includes the refinery and other industries. Another flooded area is placed along the northern bank of the river, between Hualpén and Concepción. One of the main problems in this area is the water drainage system, which is overridden by the high water levels in the Bío Bío River. The creek Los Batros and the adjacent low lands, located west of San Pedro de la Paz, receive backwaters from the Bío Bío. Furthermore, similar situations are possible to identify a few kilometres upstream of Concepción, and several flooded areas are recognized on the northern bank near the cities of Chiguayante and Hualqui (i.e. populated lands). Also it is possible to identify flooded areas of agriculture land on the southern bank, about $15 \mathrm{~km}$ upstream of San Pedro de la Paz.

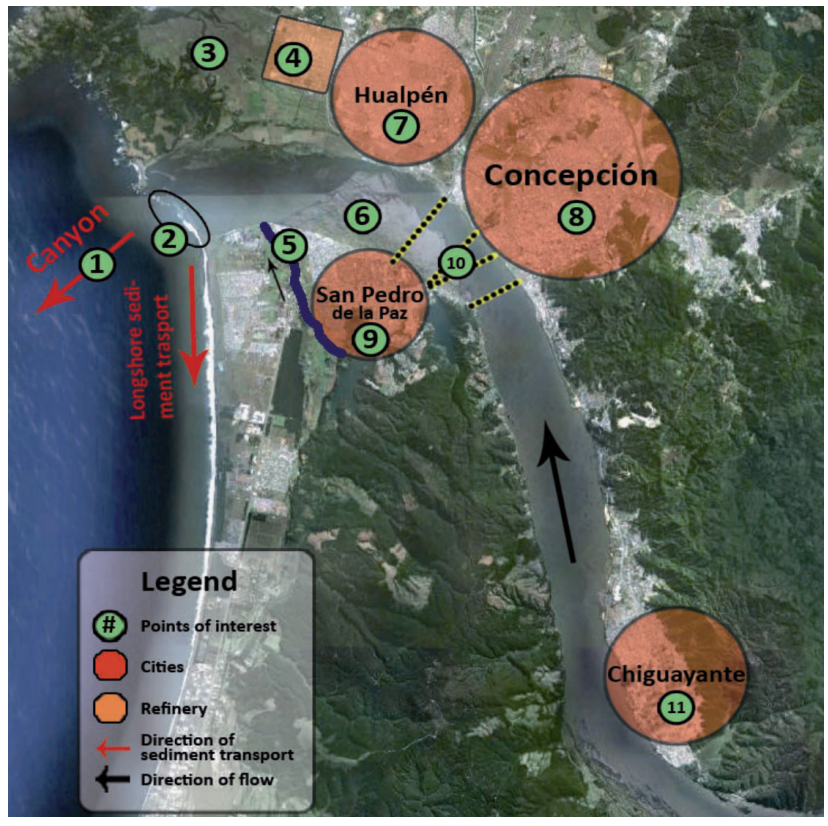

Figure 3: Key areas to be considered within the modelling process, some of them to be protected from floods
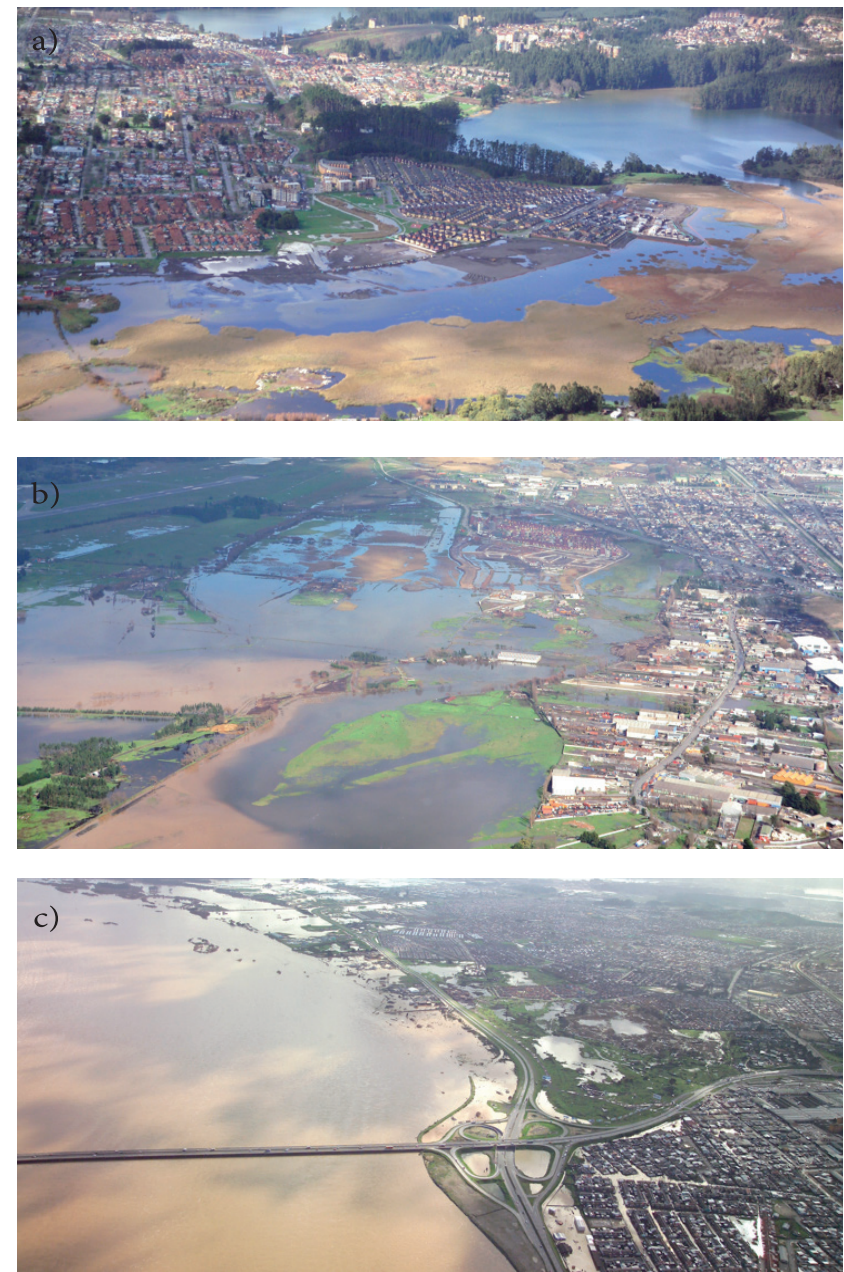

Figure 4: Aerial photograph during the 2006 flood event, a) San Pedro de la Paz, b) Talcahuano and c) Hualpén 
Morphological and hydraulic characteristics for the modelling site indicate a significant increment of the river width towards the mouth. The upstream boundary is $1100 \mathrm{~m}$ wide increasing to $2800 \mathrm{~m}$ at the river mouth. In addition, the river has a unique bend that is supported by a significant sized sand bar on the southern bank (Figure 5a). Upstream of this curvature the course is fairly straight indicating average rectangular-like cross-section shape, and the average longitudinal slope corresponds to 0.00053 $\mathrm{m} / \mathrm{m}$. The northern bank of the river is artificially protected to erosion (i.e. rubble mound dikes), and a paved road runs along it. The southern bank shows little artificial protection, but dense vegetation composed by different types of bushes and grouted trees.
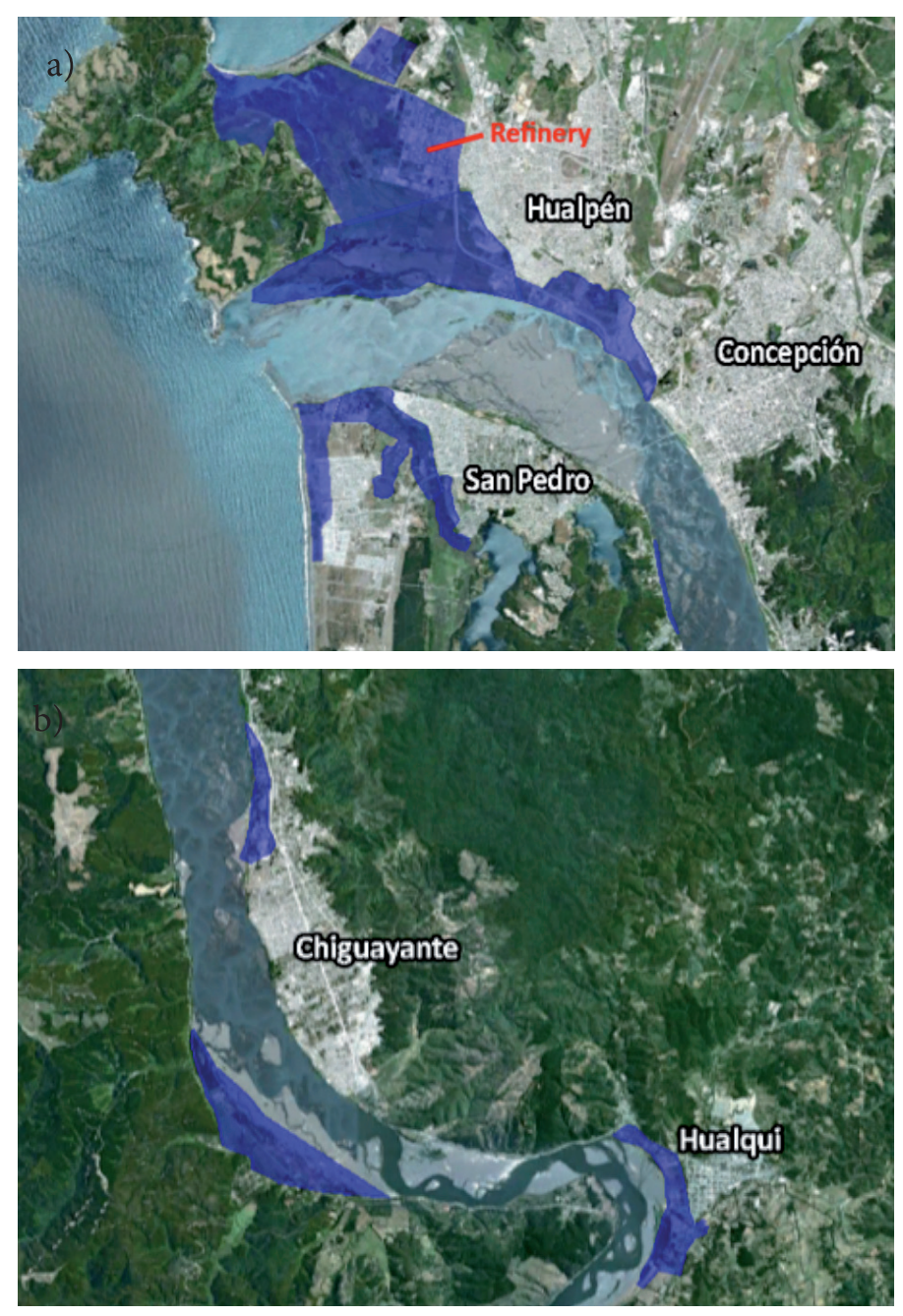

Figure 5: Identified flooded areas by means of areal photograph, a) Hualpén and b) Hualqui
The substrate found in the lower part of the river is mainly coarse and uniform sand, however its median size $d_{50}$ decreases towards the mouth. Samples of bed sediment showed that the grain sizes at the upstream and downstream boundaries of the numerical model have $d_{50}$ values of 1.03 and $0.85 \mathrm{~mm}$, respectively. Both samples indicated to be uniformly graded with ratios $d_{60} / d_{10}$ of 2.4 and 2.2. Observed bedforms were identified as dunes and ripples, which showed to move constantly at low flows. At higher flows (i.e. flood discharges) however, the increased velocities (i.e. high Froude numbers) are expected to smooth these bedforms and therefore to have little influence on roughness.

The Manning $n$ parameter was chosen to characterize roughness. Based on literature and comparisons with similar rivers (Barnes, 1967), the first estimation of the roughness coefficient for the Bío Bío River was defined to be between 0.025 and 0.037 . The final value resulted once the model calibration processes was concluded. It is important to note that there are differences between the roughness of the main channel and that on the flood plains. The presence of vegetation on the latter increases the roughness locally, determining separate calibration processes for the main channel, floodplains, vegetated floodplains and urban areas.

Discharge and water levels were obtained from the local DGA gauging station named "Estación Bío Bío en Desembocadura, Código BNA 08394001-8". The available data corresponds to an interrupted period starting in 1971 up to date with several silence ranges (Figure 6).

There is no tidal data available directly at the river mouth. However, there are two tide gauges located $10 \mathrm{~km}$ north and $20 \mathrm{~km}$ south of the mouth in the cities of Talcahuano and Coronel, respectively. Figure 7 shows an example of the available data, covering a range from September $11^{\text {th }}$ until October $5^{\text {th }}, 2012$. From Figure 7, it is possible to see that both stations show similar results, with very similar tidal records. It is concluded that the use of Talcahuano tide data provides good estimation of tidal level at the river mouth. The tide at Talcahuano is semi-diurnal with a larger daily inequality between two successive high waters than between two successive low waters. 

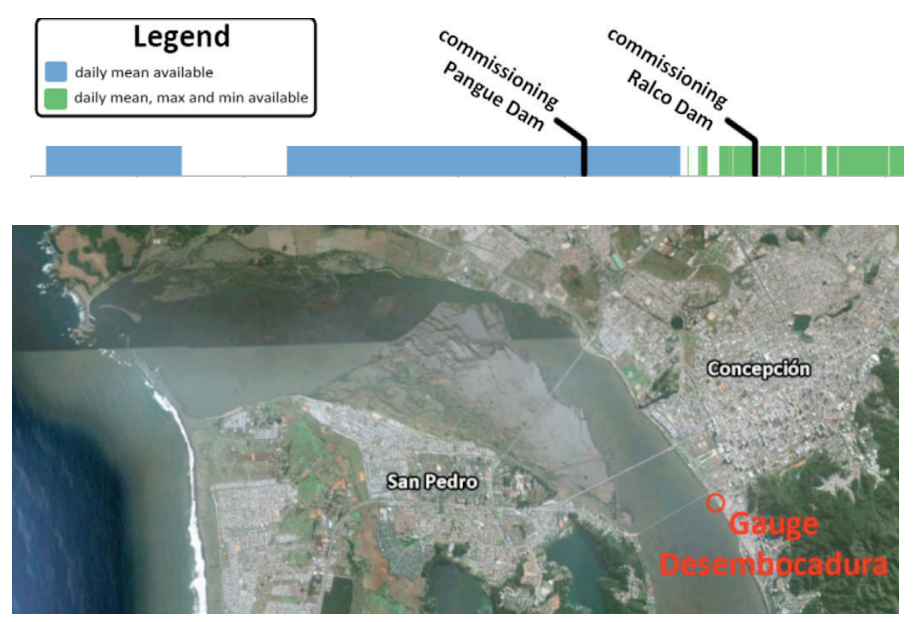

Figure 6: Bío Bío gauging station showing temporal data distribution and location
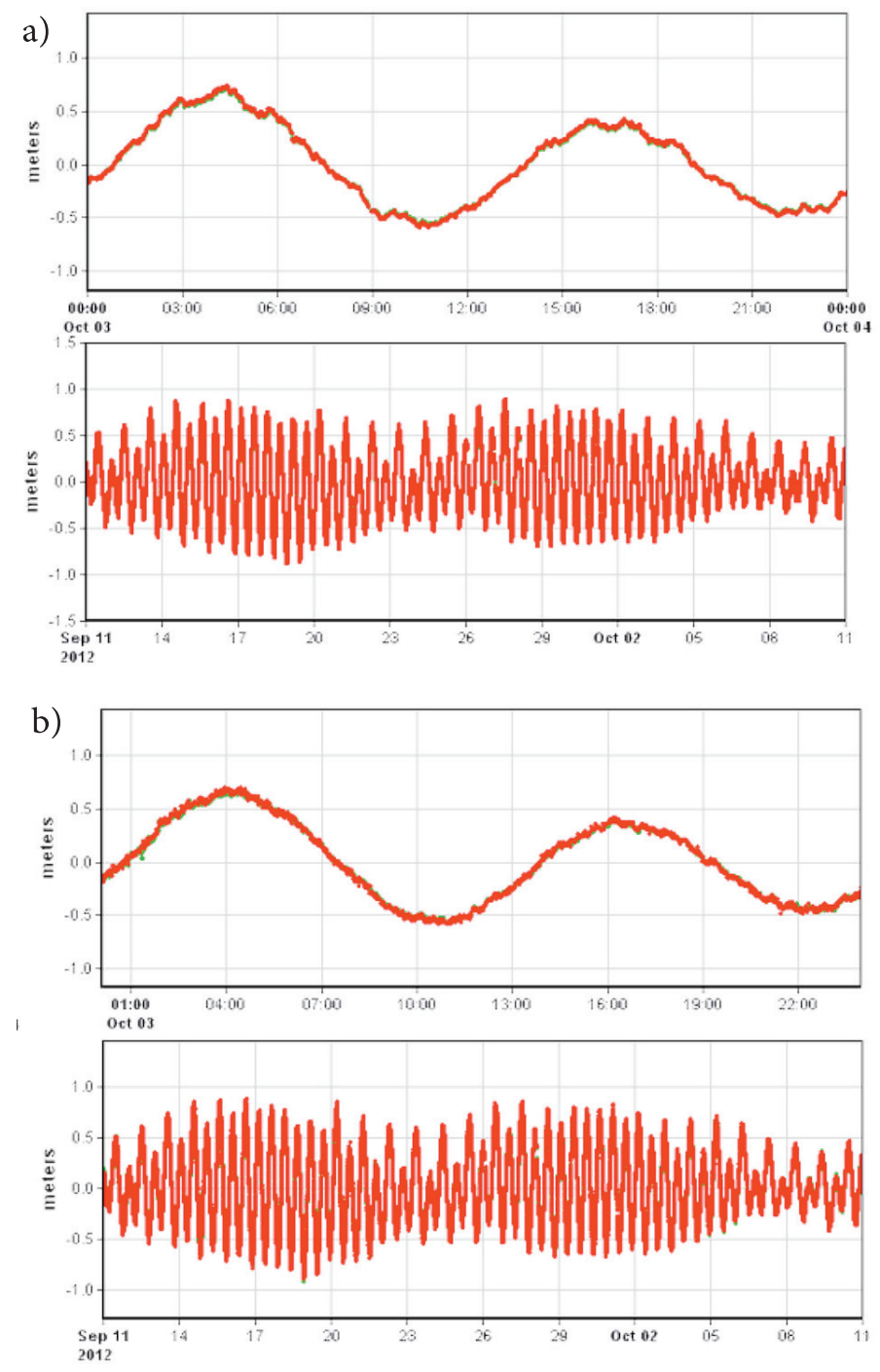

Figure 7: Tidal data from September 11 th until October 5 th given by buoys in a) Talcahuano and b) Coronel
Hydraulic calculations were performed using the software HEC-RAS, developed by the U.S. Corps of Engineers and widely used for one-dimensional modelling. The collected data was loaded in the software providing enough information to characterize the current hydraulic condition on the study area.

Numerical simulations were performed under four different downstream boundary conditions (i.e. four different steady tide levels) at high river discharges. To do this, the low tide, mean tide, high tide and the historical maximum tide level were considered. Results of the water surface profiles are shown in Figure 8. It is seen that for low, mean, and high tide levels, the influence of the boundary condition does not reach further than $500 \mathrm{~m}$ upstream of the river mouth, whereas the historical maximum level indicates an influence of about $2 \mathrm{~km}$. This distance covers approximately the lower $10 \%$ of the modelling domain. This behaviour is in good agreement with the results given by Osorio (2010), which showed an analogous variation when using bathymetric conditions surveyed in 1998.

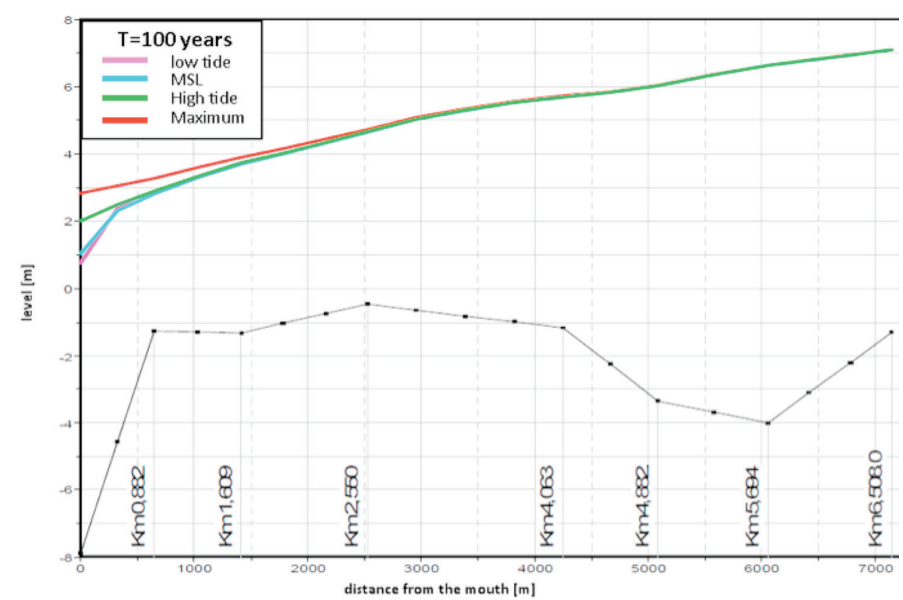

Figure 8: Water surfaces profiles for the same discharge and different tide levels on the downstream boundary conditions

Calibration was done using discharge versus water level relationships (i.e. discharge-rating curve) while adapting the friction characteristics. The friction was determined by the Manning roughness parameter, which was iteratively calculated until the discharge-rating curve, obtained from the model, reached the best fit with the measured discharge-rating curve at the Desembocadura gauging station. HEC-RAS spatially characterizes roughness, and for that reason four areas were identified as different 
sources of friction. Figure 9 shows the four friction areas, identify as: the main channel, low to medium vegetation, dense vegetation, and urban areas. It is important to note that the purple coloured part of the southern floodplain, indicated with number 1 , shows a large spatial variation in vegetation. This vegetation has been growing and establishing on the inner sand bar, helped by the increasing deposition during the last 10 years (Fernández, 2013). As a result of this process, the roughness on the side sand bar has increased significantly. While, the area indicated with number 2, presents increments on vegetation cover but not at the level of the sand bar. Table 1 shows the initial and final roughness values during the calibration process. These final roughness values were used in the model in order to assess the different alternatives to reduce the flooding effects. Finally, Figure 10 resumes the calibration results.
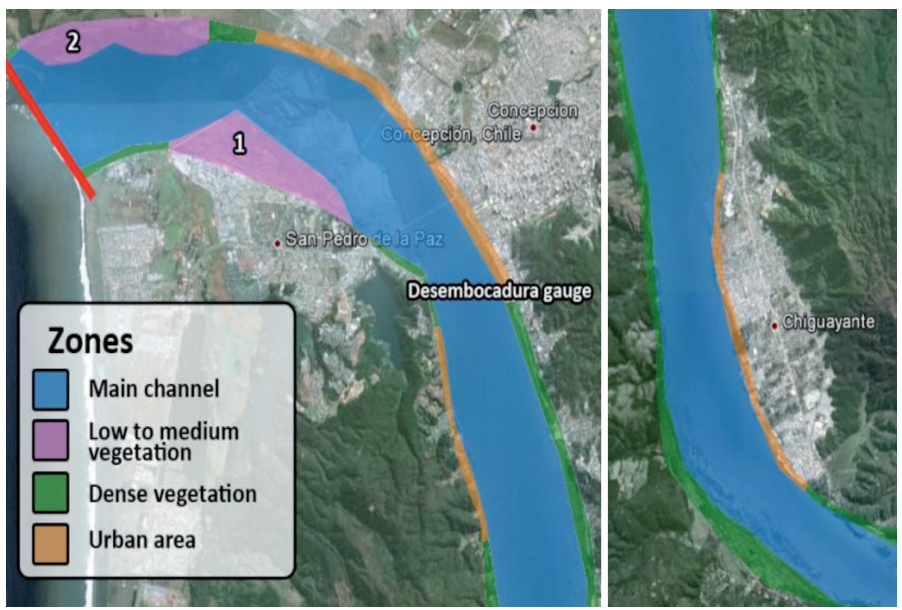

Figure 9: Roughness spatial characterization within the study reach (identified between redlines).

Table 1: Values of Manning coefficient $n$ considered

\begin{tabular}{|l|c|c|c|}
\hline \multicolumn{1}{|c|}{ Zones } & $\begin{array}{c}\text { Initial } n, \\
\mathrm{~s} / \mathrm{m}^{1 / 3}\end{array}$ & $\begin{array}{c}\text { Variability in } \\
\text { calibration } \\
\text { process }\end{array}$ & $\begin{array}{c}\text { Final } n, \\
\mathrm{~s} / \mathrm{m}^{1 / 3}\end{array}$ \\
\hline Main channel & 0.033 & variable & 0.029 \\
\hline $\begin{array}{l}\text { Low to medium } \\
\text { vegetation }\end{array}$ & 0.04 & variable & 0.04 \\
\hline $\begin{array}{l}\text { Dense } \\
\text { vegetation }\end{array}$ & 0.07 & not variable & 0.07 \\
\hline Urban areas & 0.10 & not variable & 0.10 \\
\hline
\end{tabular}

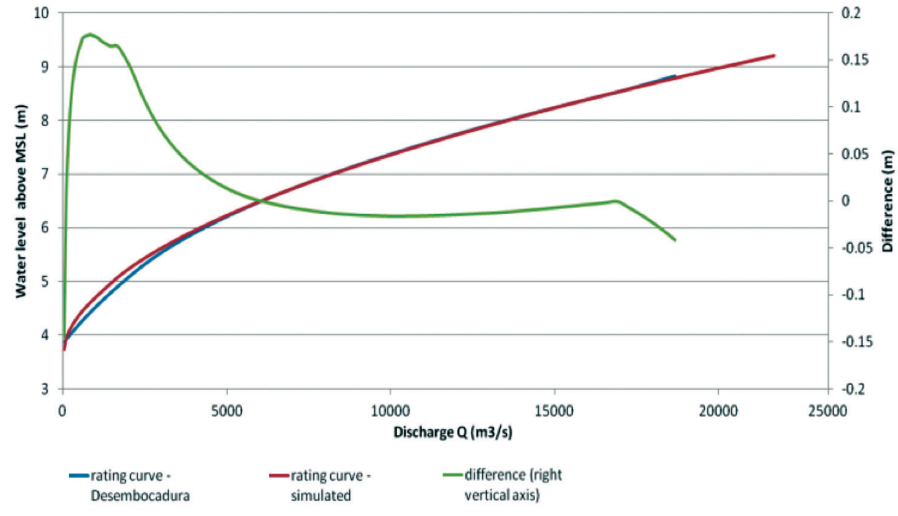

Figure 10: Water level comparison between measured and calibrated rating curves

\section{Proposed countermeasures}

The calibrated model was used as a predictive tool. Results of the current modelling conditions indicated several flooding areas along the southern and northern riverbanks (Figure 11). Based on these results four different strategies were considered to reduce the floodwater surface elevation. In addition, some approaches considered several alternatives as follows:

\section{Discharge volume reduction}

- New storage volume upstream the study-reach

- Temporary storage volume inside the project area

- Storage capacity of the Ralco and Pangue dams

2. Increasing river transport capacity

- Developed new floodplains

- A bypass channel to the ocean through the old river course

3. Increase of the critical depth

- Increase of the current levee heights

- Dredging of the main channel and flood plains 4. Reduction of the roughness

- Reduction of the roughness on the riverbed

The utilized data does not supply enough topography information behind the riverbanks, and therefore, it is hard to determine the best location for the levees across each profile. In the present study, these locations are given as longitudinal distance, and it is recommended to perform additional topography of the critical areas and their surroundings, in order to determine the best levee locations. 
a)

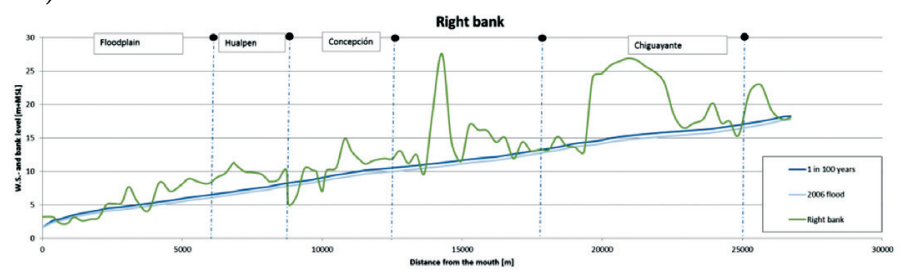

b)

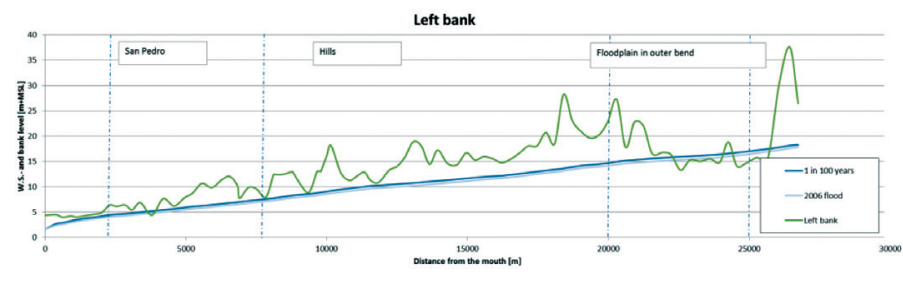

c)

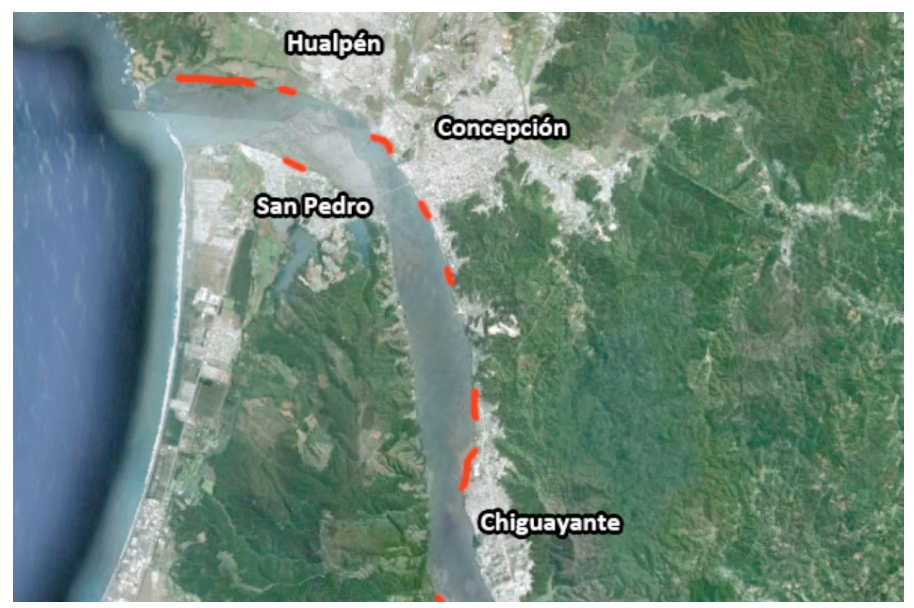

Figure 11: Indicates the water surface elevation along the river bank height for the a) right and b) left banks, and c) critical areas on both banks, shown by red lines

\section{Results}

A preliminary assessment was performed in order to select the four most promising alternatives to be considered in the numerical modelling. Details of this analysis are given by van Heemst et al. (2012). The main results of the four selected alternatives are given bellow.

\section{Raising current levees}

By raising the levees along the River Bío Bío, higher water levels can be retained. Objection to a levee system is the flow of rainwater from Concepción into the river, which may be obstructed due to the projected new higher levels. The option of raising the levees remains important to look further into it, because it seems to protect the critical areas directly.

Figures 12 and 13 show the difference in height between the required crest height and the height of the highest data point on the bank according to the bathymetrical data at the southern and northern riverbank, respectively. The red highlighted areas indicate critical areas where the levees height should be increased, while green highlighted areas represents low areas but no critical, thus the levee height do not need to be increased. In addition, the indentified locations were numbered from 1 to 10 in both figures. It is important to mention that most of the critical areas correspond to developed areas; therefore, overtopping of current levees could generate damage in properties and individuals. Table 2 shows the estimated dimensions, such as height and length, for the 10 locations identified in Figures 12 and 13. The locations 4 and 5 are not described due to the fact that these areas are not critical and the levee height can be maintained. However, location 6 is considered a special case, because urban and industrial areas are located behind this levee and large inundation occurred in 2006, as shown in Figure 5. A more comprehensive analysis of this location is given in the following paragraphs.

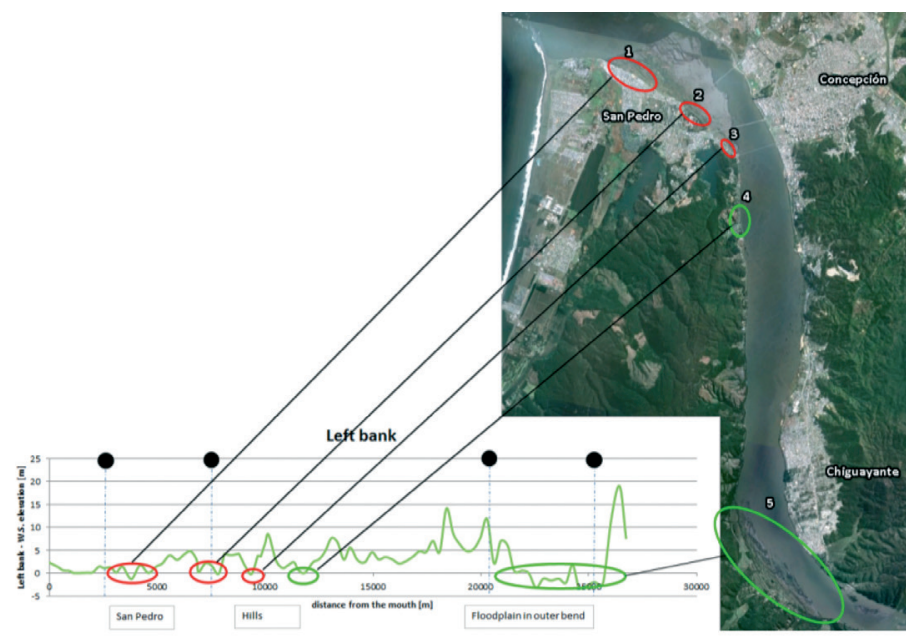

Figure 12: Locations on the left bank where current levee height is insufficient, in red the locations are critical and levee height should be increased. In green locations are not critical and levee height can be maintained

At location 6, a levee is necessary to the city of Hualpén. Option a) which considers to build a levee between Hualpén and the floodplain, and option b) considers to build a levee at the Bío Bío south riverbank, which additionally avoids flooding of the wetlands. Option b) is preferred since the necessary length and height of the levee are smaller. Additionally, this option protects present infrastructure and houses, which are situated on the wetlands. It is recommended to do further studies on the 
ecological changes for these wetlands. In addition, tsunami inundation maps of Hualpén have shown that wetlands are also prone to be inundated in case of seawater surging the Bío Bío River, therefore, the levee could also protect in case a large tsunami attack. However, the wetlands are also exposed to the Bay of San Vicente, subsequently the protection against tsunami must be analyzed with caution.

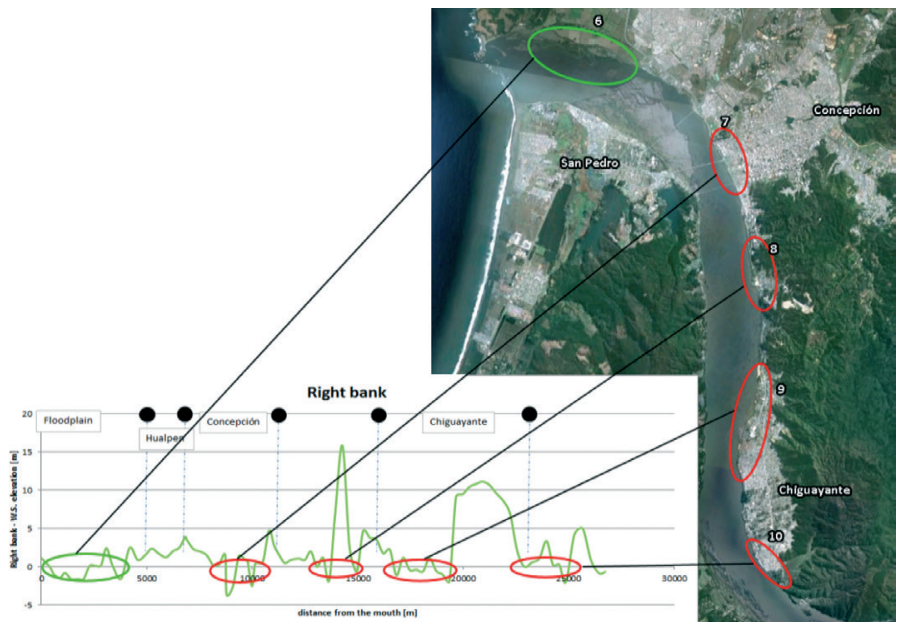

Figure 13: Locations where current levee height is insufficient along the right bank. In red the locations are critical and levee height should be increased. In green the locations that are not critical, and thus, levee height can be maintained

Table 2: Estimated levee dimensions of the 10 locations identified in the lower part of the Bío Bío River

\begin{tabular}{|c|c|c|c|}
\hline $\begin{array}{c}\text { Levee } \\
\text { number, } \\
\text { location }\end{array}$ & $\begin{array}{c}\text { Design crest } \\
\text { height above } \\
\text { MSL, } \mathrm{m}\end{array}$ & $\begin{array}{c}\text { Bank average } \\
\text { height below } \\
\text { design level, } \mathrm{m}\end{array}$ & $\begin{array}{c}\text { Length, } \\
\mathrm{m}\end{array}$ \\
\hline 1 & 5.2 & 1.5 & 500 \\
\hline 2 & 7.3 & 0.5 & 500 \\
\hline 3 & 8.6 & 0.5 & 300 \\
\hline 6 & 4.2 & 1.4 & 1500 \\
\hline 7 & 8.5 & 3.0 & 1000 \\
\hline 8 & 11.6 & 1.2 & 900 \\
\hline 9 & 14.0 & 1.0 & 2000 \\
\hline 10 & 16.5 & 2.0 & 1000 \\
\hline
\end{tabular}

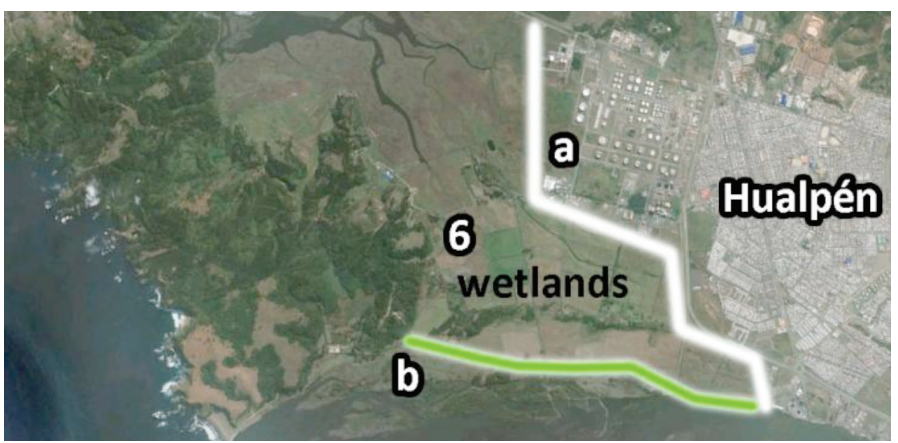

Figure 14: Option a: levee located along the city of Hualpén, and option b: levee located along the Bío Bío river north bankBypass channel

\section{Bypass channel}

The effect on the water level of a bypass channel through the floodplain west of Hualpén to the ocean is determined in this paragraph. The exact location of such a bypass channel has been determined based on the channel junction. Since it should be located as upstream from the river mouth as possible. Figure 15 indicates the location considered for the analysis of this channel. The channel is modelled as a withdrawal of water located $4.2 \mathrm{~km}$ upstream of the river outlet. The effect on the water surface elevation within the project area is checked for different channels by varying the discharge capacity (Figure 16). The water levels are compared with the design water level. The effects in the river are checked considering a channel with a discharge of 10000,6000 and $2000 \mathrm{~m}^{3} / \mathrm{s}$.

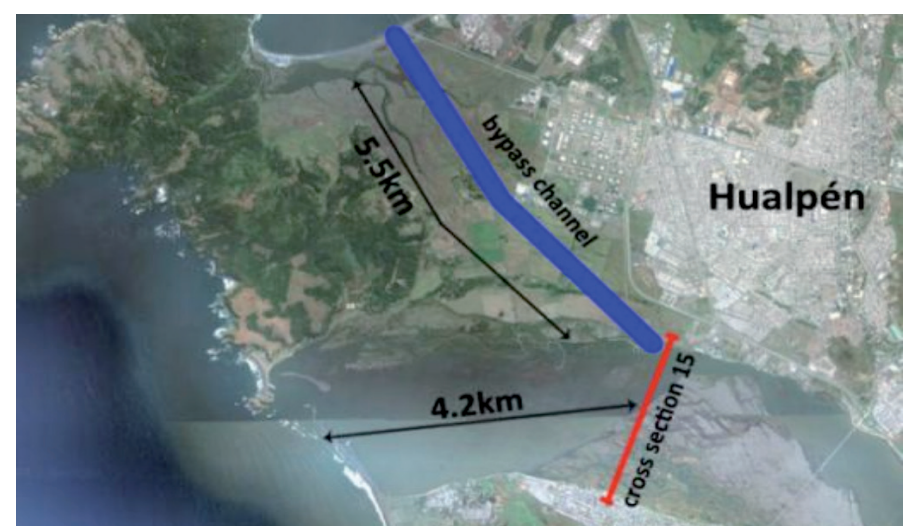

Figure 15: Bypass channel considered location.

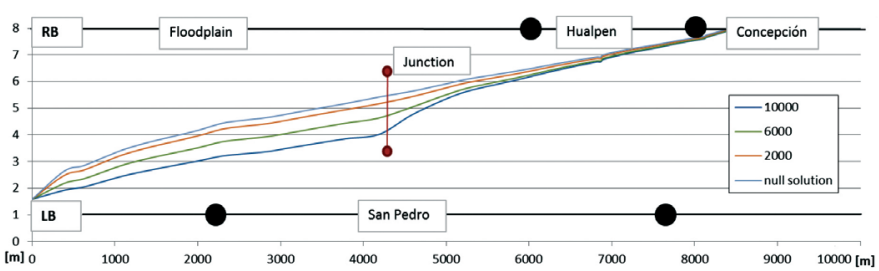

Figure 16: Water surface elevation reduction along the Bío Bío River provided by the proposed bypass channel. RB: short for Right Bank, LB: short for Left Bank

Figure 16 shows that the bypass channel is very effective in lowering the water levels downstream its water intake. This will reduce the risk for future floods in the creek of San Pedro and for the wetlands west of the bypass channel. Upstream of the junction, however, the effects are very limited. Only $3 \mathrm{~km}$ upstream of the junction the reduction of the water level is already negligible. In addition, it is important to study possible morphological consequences 
for the river if this alternative is chosen (i.e. local erosion on the south bank), and further research should be carried out on this matter.

\section{Reduction in roughness}

Roughness can be lowered on certain places by cutting away the present vegetation (i.e. especially at the southern floodplain in the river bend near San Pedro). To simulate the effect on the water level with a decreased roughness, the roughness coefficient assigned to the floodplain is lowered in the HEC-RAS model and the effect on the water surface elevation is computed.

It is difficult to accurately determine how much the roughness is reduced after removing the vegetation, and further tests need to be carried out in order to improve this portion of the study. However, an extreme situation can be quantified by comparing a densely vegetated floodplain scenario $\left(n\right.$-value of $\left.0.07 \mathrm{~s} / \mathrm{m}^{1 / 3}\right)$ with a floodplain roughness equal to the one defined for the main channel ( $n$-value of $\left.0.029 \mathrm{~s} / \mathrm{m}^{1 / 3}\right)$. The difference between those two scenarios is used to analyze the effect of this alternative. Figure 17 shows the water surface elevations with a dense vegetated floodplain and no vegetation at all. The difference in water surface elevation is plotted as well in the same figure. Although the effects upstream and downstream of the floodplain are negligible, it is possible to see that there is a reduction in water surface elevation at the location of the floodplain quantified in $0.5 \mathrm{~m}$. It is important to mention that all the alternatives studied in this work assume a fixed bed, which means that the effects on sediment transport due to the decreasing vegetation have to be investigated as well.

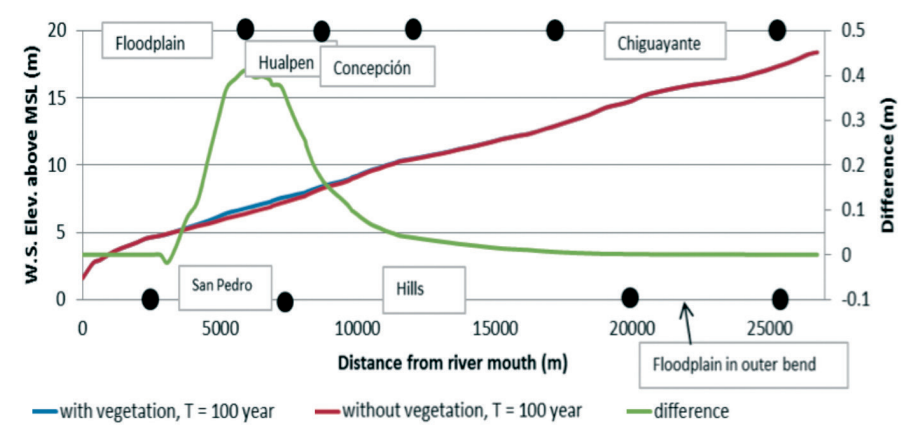

Figure 17: The effect of vegetation changes on the sand bar located on the south river bank

\section{Use of upper Bío Bío reservoir as storage volumes}

An alternative to reduce the floodwater surface elevation in the project area is to reduce the flood discharge by using the reservoirs of the Pangue and Ralco dams as extra storage volume (García et al., 2010). The biggest advantage of this alternative is that no additional infrastructure needs to be built.

Approximately $40 \%$ of the average annual discharge at the mouth flows downstream the river through the DGA measuring gauging station Bío Bío at Rucalhue, located $45 \mathrm{~km}$ downstream the main course. Therefore, different hypothetical ranges of reservoir storage are assumed, and these are capable to reduce the maximum design discharge (van Heemst et al., 2012) at the lower portion of the Bío Bío River (Table 3).

Table 3: Different assumed discharge reductions due to storage in the upstream reservoirs

\begin{tabular}{|c|c|}
\hline Reduction factor, $\%$ & $\begin{array}{c}\text { Maximum design } \\
\text { discharge, } \mathrm{m}^{3} / \mathrm{s}\end{array}$ \\
\hline 0 & 20400 \\
\hline 5 & 19380 \\
\hline 10 & 18360 \\
\hline 20 & 16320 \\
\hline 40 & 12240 \\
\hline
\end{tabular}

Figures 18 and 19 show the results of the numerical model for reduced discharge inputs to the river. Even when $40 \%$ of the peak volume is reduced, there are still areas along the banks where the water will overtop the existing levees and will flood urban areas.

A design discharge reduction of $40 \%$ seems to be effective in lowering the water surface elevation in more than $1 \mathrm{~m}$ in most sections of the project area. However, lowering the water surface elevation to this extend is not enough to solve the problems at all critical locations. Wherever the shortcoming height exceeds the water level reduction, overtopping will still occur during flood conditions. For example, when considering the water surface elevation with a reduction of $40 \%$, the wetlands and parts of Hualpén and Concepción should be flooded, including the outer bend upstream of Chiguayante. 


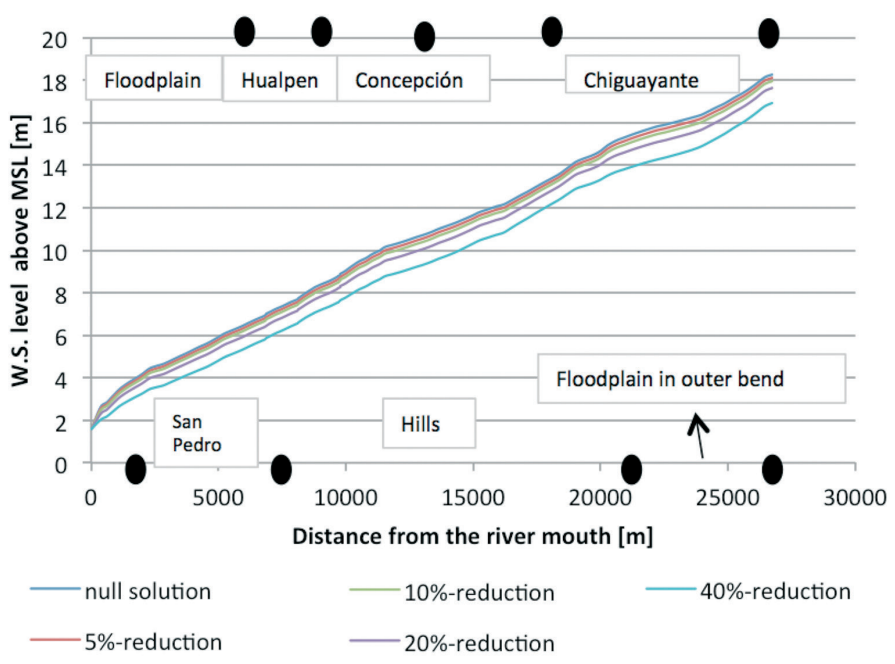

Figure 18: Water surface elevation for different storage percentage

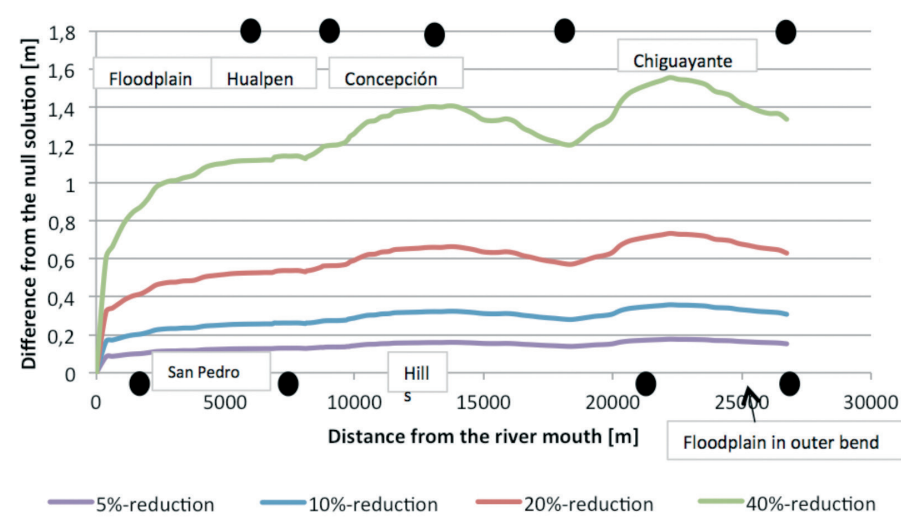

Figure 19: Reduction in water surface elevation for different storage percentage

\section{Combining alternatives}

From the previous analysis, it is seen that none of the four alternatives completely meet the demands and requirements to avoid flood areas. However, a combination of different alternatives can provide a satisfying solution. Important conclusions about the alternatives are summarized and identified in Table 4.

The bypass channel is expensive and does not provide a reduction of the water level for the entire project area. Therefore, the alternative of a bypass channel through the northern floodplain is discarded as a feasible approach for lowering the risk of future river floods.

It can be concluded that rising of the levees is the only measure that provides safety for the entire project area during design conditions. However, combining the levees with maximum storage by the upstream reservoirs and a reduction on roughness on the lower part of the Bío Bío River (i.e. clearing it from vegetation) allows the reduction of the projected levee height by $1.5 \mathrm{~m}$. This reduction should be considered as an upper boundary.

\section{Conclusions}

A model simulation of the present situation during design conditions is carried out and the water surface elevation is compared to the present bank heights. Critical locations are designated around Hualpén, Concepción, San Pedro de la Paz and Chiguayante. Four alternatives are elaborated to reduce risks, and it is concluded that the bypass channel is not feasible. Both, removal of the vegetation on the floodplains and using the dam reservoirs as storage volumes, are insufficient in solving all relevant flood problems. This is why a levee system is inevitable for the development of a flood defence system. Also a combination of measures in order to reduce the levee height could be used. The proposed design heights of the levees can be lowered by storing water in the dam reservoirs during high water peaks and by removing the vegetation on the floodplains in order to lower the bed roughness. These results support the materialization of reservoir emergency operation protocols, as indicated in the Reglamento de Ley No20.304, approved by Decreto de Ley 138, Chile.

As a continuation of this study, it is recommended to carry out additional studies in order to make more accurate estimations. With the aid of these additional studies, further elaboration of the alternatives is advised. The following model improvements would be of great value and are recommended:

- A thorough study on the bed friction of both, the main channel and floodplains.

- A study on discharge-water level relations just upstream of the project area. These relations should be used to optimize the calibration process. This will improve the accuracy of simulated water levels upstream of the gauging station.

Additionally, computation of sediment transport loads 
Table 4: Overview of different alternatives

\begin{tabular}{|l|l|l|l|l|}
\hline Alternative & Levee system & Bypass channel & $\begin{array}{l}\text { Removal of the } \\
\text { vegetation }\end{array}$ & \multicolumn{1}{|c|}{ No } \\
\hline $\begin{array}{l}\text { Ability to solve } \\
\text { complete problem }\end{array}$ & \multicolumn{1}{|c|}{ Yes } & \multicolumn{1}{|c|}{$\begin{array}{l}\text { Nom reservoirs as } \\
\text { storage volumes }\end{array}$} \\
\hline Implementation & $\begin{array}{l}\text { A complete new levee } \\
\text { system has to be built }+ \\
\text { corresponding adaptations of } \\
\text { the drainage system }\end{array}$ & $\begin{array}{l}\text { A channel has to be } \\
\text { dug and surrounding } \\
\text { levees have to be built }+ \\
\text { corresponding adaptations } \\
\text { to the drainage system }\end{array}$ & $\begin{array}{l}\text { Can be implemented } \\
\text { immediately }\end{array}$ & $\begin{array}{l}\text { Requires a change of } \\
\text { existing regulations }\end{array}$ \\
\hline Intrusiveness & $\begin{array}{l}\text { Levees demand space and } \\
\text { somehow obstruct the view } \\
\text { on the river }\end{array}$ & $\begin{array}{l}\text { Channels and levees } \\
\text { require a lot of space } \\
\text { and divide the urban and } \\
\text { wetland areas }\end{array}$ & $\begin{array}{l}\text { Change of the } \\
\text { floodplain's appearance. } \\
\text { During floods the same } \\
\text { will happen though }\end{array}$ & No intrusive changes \\
\hline Maintenance & $\begin{array}{l}\text { Levees need to be } \\
\text { maintained }\end{array}$ & $\begin{array}{l}\text { Channel needs to be } \\
\text { maintained a lot }\end{array}$ & $\begin{array}{l}\text { Consists of maintenance } \\
\text { work only }\end{array}$ & $\begin{array}{l}\text { No additional } \\
\text { maintenance }\end{array}$ \\
\hline Costs & Medium & High & Low & Medium \\
\hline
\end{tabular}

is necessary to include morphological changes in the analysis and to proposed long-term measures. Moreover, bi-dimensional hydraulic modelling is also recommended to better estimate spatial distribution of water velocity, bed and bank erosion/accretion and flood behaviour. Since the level of volume reductions by the reservoirs is critical for the levee design is recommended to quantify the maximum potential retention volumes under different discharge scenarios. In order to quantify the levee exact location and its structure dimensions it is necessary extra topographical data, especially on the banks and floodplains. The actual advantages and disadvantages of a levee system should be determined and taken into account. This together will allow a well-founded cost estimation.

\section{Acknowledgements}

The authors would like to acknowledge the Dirección General de Aguas DGA de la Región del Bío Bío, special merit for Mrs. Isabel Drews who was always willing to help and contribute to the study. Extra support was obtained from project Fondecyt $\mathrm{N}^{\mathrm{o}} 11100399$. We would also like to acknowledge the funding provided from Van Oord and Royal Haskoning DHV and their continuous support.

\section{References}

Barnes, H. (1967). Roughness Characteristics of Natural Channels. Washington, USGS

Caamaño, D. (2010). Sustainability of morphology features in alluvial rivers and coastal systems in Chile: the Bío Bío River as study case. FONDECYT project No11100399

Fernández, M. (2013). Cambios morfológicos y efectos en las velocidades y alturas del flujo en la parte bajo del río Bío Bío. Memoria de título de Ingeniero Civil, Universidad Católica de la Santísima Concepción, Chile

García, A., Jorde, K., Habit, E., Caamaño, D. and Parra, O. (2011). Downstream environmental effects of dam operations: changes in habitat quality for native fish species. River Research and Applications 27(3); 312-327

MOP Ministerio de Obras Públicas (2004). Mediciones realizadas en el río Bío Bío. Concepción.

ONEMI (2012). http://www.onemi.cl/

Osorio, R. (2010). Informe eje hidráulico río Bío Bío. Concepción.

Parra, O. (2006). The Bío Bio River basin. Centro EULA, Universidad de Concepción 
U.S. Army Corps of Engineers (2010). HEC-RAS, River Analysis System, Hydraulic Reference Manual. Davis, CA.

van Heemst, C., Weller, A.H.C., van Verseveld, H.C.W. and Willems, J.A. (2012). A flood defence strategy for the Greater Concepción. Analysing, modelling and finding engineering solutions for the Bío Bío floods. Master course report, Delft University of Technology and Universidad Católica de la Santísima Concepción 